\title{
CONTRIBUTIONS TO THE BRYOPHYTE FLORA OF THE KOMOVI MTS (MONTENEGRO)
}

\author{
B. PAPP ${ }^{1}$, S. DragiĆEvić ${ }^{2}$ and P. ERZbergeR ${ }^{3}$ \\ ${ }^{1}$ Department of Botany, Hungarian Natural History Museum, \\ H-1476, Budapest, Pf. 222, Hungary; pappbea@bot.nhmus.hu \\ ${ }^{2}$ Natural History Museum of Montenegro, Trg Bećir-bega Osmanagića 16, Podgorica 374, Montenegro; \\ sneza.dragicevic@t-com.me \\ ${ }^{3}$ Belziger Str.37, D-10823 Berlin, Germany; erzberger.peter@googlemail.com
}

\begin{abstract}
As a result of several field trips made into the Komovi Mts, 200 bryophyte taxa ( 43 liverworts and 157 mosses) were collected. Four species are reported for the first time in the country. Among the species recorded, six are red-listed in Europe.
\end{abstract}

Key words: liverworts, mosses, new national records, red-listed species

\section{INTRODUCTION}

In spite of intensive bryological field explorations carried out in Montenegro, current knowledge of the bryophyte flora of this area is still far from complete. Regarding the bryophytes of Montenegro, recent summarisations are found in liverwort and moss checklists of SE Europe and the Mediterranean (Ros et al. 2007, 2013, Sabovljević and Natcheva 2006, Sabovljević et al. 2008). The liverwort checklist (Ros et al. 2007) contains 106 species from Montenegro. Subsequently, 43 additional liverworts were reported from the country in other works (Erzberger and Papp 2007, Erzberger et al. 2008, Papp and ERZBerger 2007, PAPP et al. 2008, 2013a). The most recent moss checklist (Ros et al. 2013) reports 527 mosses from Montenegro. 14 additional moss species were reported in PAPP and ERzBERger (2011) and PAPP et al. (2013a).

In the present paper we publish the complete floristical results of the collecting trips to the Komovi Mts made in 1998, 2006 and 2008.

\section{MATERIAL AND METHODS}

Study area

Komovi Mts are located in the eastern part of Montenegro as part of the Dinaric Mts (Fig. 1). It has the shape of a horseshoe and is about $40 \mathrm{~km}$ long and $30 \mathrm{~km}$ wide. It is surrounded by plateaus with average altitude of $1,900 \mathrm{~m}$ 
a.s.l. (Štavna and Ljuban in the north, Rogam in the west, Crnja in the south and Varda in the west). The upper part of the Lim river forms the eastern border of the Komovi Mts, whereas the western border is formed by the canyon of the Tara river. The highest peaks are Kučki Kom (2,487 m), Ljevorečki Kom (2,469 m) and Vasojevićki Kom (2,460 m).

The largest part of the Komovi Mts, especially the eastern and southeastern segments, is built up of Palaeozoic shales, sandstones and conglomerates, into which the rivers Tara, Lim and their tributaries have carved deep val-

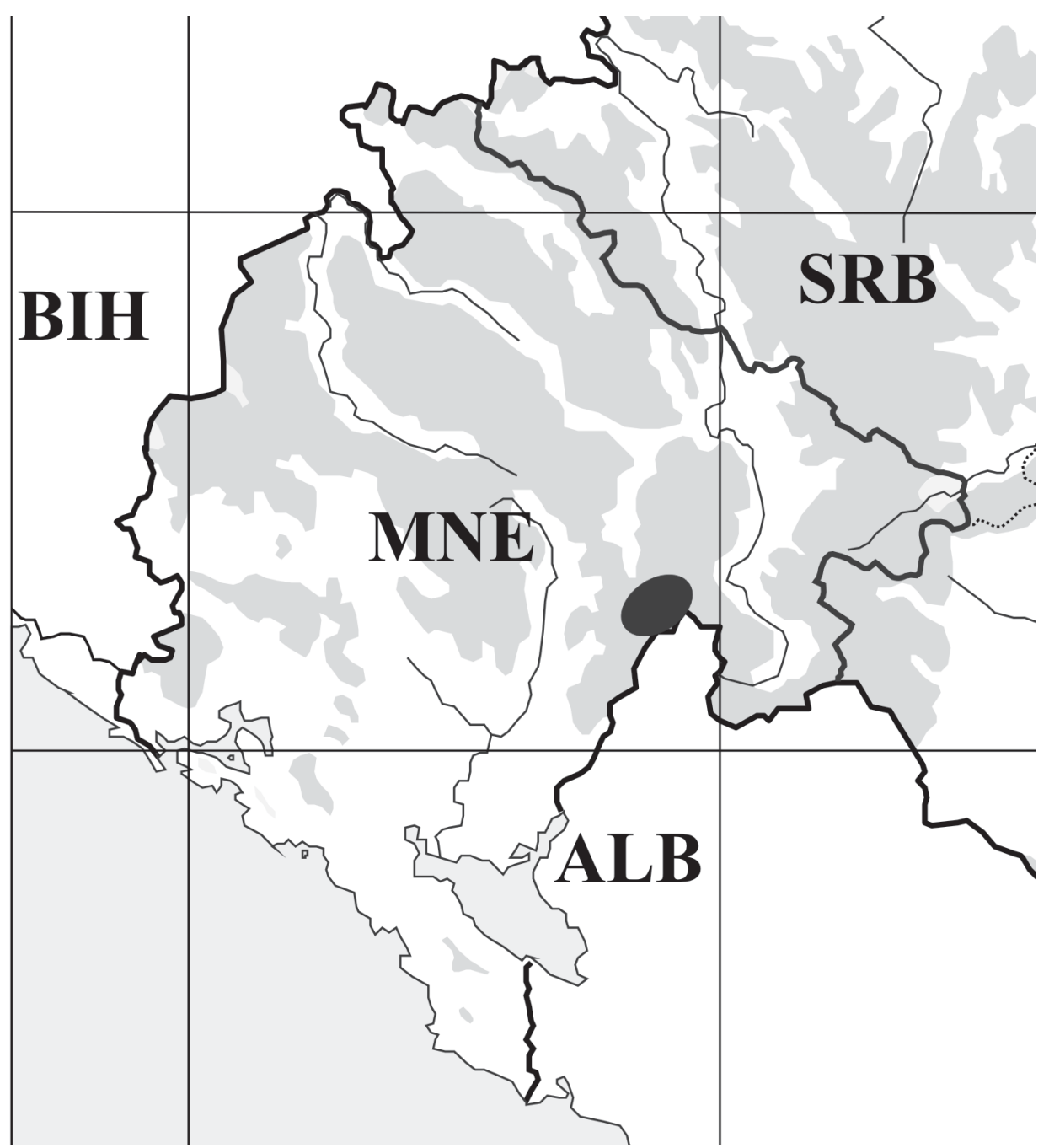

Fig. 1. Location of the investigated area 
leys. Other parts of the mountains are characterised by limestone bedrock. Geomorphologically, the Komovi Mts were affected by intense glaciations, which is evidenced by numerous cirques. At higher altitudes strong erosion processes have led to the emergence of large moraines, especially on the southern slopes of Kučki Kom (Kićović and Dragović 2000).

Komovi Mts possess a dense hydrographical network. On the southern slopes of Kučki Kom, the source area of the longest river of Montenegro, the Tara river, can be found. Numerous streams of the northern slopes of the Vasojevićki Kom (e. g. Perućica, Kutska, Zlorečica) flow into the Lim river (KIćović and Dragović 2000).

Generally, the Komovi Mts are characterised by temperate continental (up to $900 \mathrm{~m}$ a.s.l.) and mountain climates, practically meaning moderately cold to cold and mostly humid weather conditions with a mean annual temperature of about $3-8{ }^{\circ} \mathrm{C}$ and annual precipitation of 700-2,500 mm (KIćović and DRAGOVIĆ 2000).

The massif of the Komovi Mts has a very rich and still well preserved flora. Up to $1,800 \mathrm{~m}$ a.s.l. the area is covered by various forest types, e.g. beech, beechconiferous and then pure pine forests. LAKUŠIć (1974) found a great variety of rare, endemic and relict forest communities e.g. Pino-Amphoricarpetum bertiscei, Linario-Daphneetum oleoidis, Roso-Juniperetum nanae, Salicetum grandifoliae montenegrinum, Fago-Aceretum visianii, Asyneumo-Fagetum moesiacae, Pinetum heldreichii bertiscum and others. At higher altitudes, there are open habitats (scree, rocky grasslands, alpine meadows), which also support a large number of endemic species. Petrović et al. (2012) reported nine Natura 2000 habitat types: alpine and boreal heaths, alpine and subalpine calcareous grassland, species-rich Nardus grasslands on siliceous substrates in montane and submontane areas in continental Europe, hydrophilous tall herb fringe communities of plains and of the montane to alpine levels, mountain hay meadows, calcareous and calcshist screes of the montane to alpine levels (Thlaspietea rotundifolii), calcareous rocky slopes with chasmophytic vegetation, Luzulo-Fagetum beech forests, and high Oro-Mediterranean pine forests.

\section{Site details}

1. Komovi Mts, plateau Štavna, 1,787 m, N 42 42' 15.8”, E 19 40' 54.7”, 25.07.2006 and 27.07.2008, leg. Dragićević, $S$.

2. Komovi Mts, from plateau Štavna to peak Vasojevićki Kom, $1,810-2,460 \mathrm{~m}$, between $\mathrm{N} 42^{\circ} 42^{\prime}$

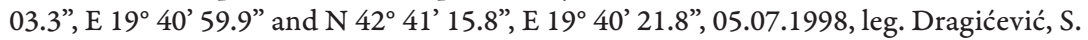

3. Komovi Mts, Margarita, below Rogamski Kom, 1,768-1,893 m, between N $42^{\circ} 41^{\prime} 54.3^{\prime \prime}$, E $19^{\circ}$ 36' 56.2" and N 42 41' 15.4', E $19^{\circ} 37^{\prime}$ 57.3”, 13.08.2008, leg. Dragićević, S.

4. Komovi Mts, Margarita, stream Valove, 1,817 m, N 42 41'30.7”, E 19³7’ 7.5”, 13.08.2008, leg. Dragićević, $S$. 
5. Komovi Mts, Margarita, spring Bijeli izvori, 1,972 m, N 42 41’ 01.6”, E 19³7’ 56.0”, 13.08.2008, leg. Dragićević, S.

6. Komovi Mts, pasture Ljuban, 1,812 m, N 42 42’ 04.9”, E $19^{\circ} 39^{\prime}$ 20.1”, 25.07.2006, leg. Dragićević, S.

7. Komovi Mts, near pasture Kojići, 1,829-1,876 m, between N 42 41'36.3”, E $19^{\circ} 37^{\prime} 30.6^{\prime \prime}$ and N 42 41' 46.8”, E $19^{\circ} 36^{\prime} 55.5^{\prime \prime}, 13.08 .2008$, leg. Dragićević, S.

8. Komovi Mts, from plateau Štavna to pasture Ljuban, $1,787-1,812 \mathrm{~m}$, between N $42^{\circ} 42^{\prime} 15.8^{\prime \prime}$, E 19 40' 54.7' and N 42 42' 04.9”, E 19³9' 20.1', 25.07.2006, 28.07.2008. leg. Dragićević, S.

9. Komovi Mts, valley Ljubaštica to pasture Ljuban, 1,569-1,812 m, between N $42^{\circ} 41^{\prime} 35.6^{\prime \prime}$, E $19^{\circ}$ 39' 50.1" and N 42 42’ 04.9”, E 19³9' 20.1”, 26.07.2006, leg. Dragićević, S.

10. Komovi Mts, from plateau Štavna to pasture Ljuban, between N $42^{\circ} 42^{\prime} 27.4^{\prime \prime}, \mathrm{E}^{\circ} 9^{\circ} 40^{\prime} 41.5^{\prime \prime}$ and N 42 41' 44.3”, E 19 33'43.5”, 1,770 m, 27-28.07.2008, leg. Papp, B. and Erzberger, P.

11. Komovi Mts, plateau Štavna towards Vasojevićki Kom peak, between N $42^{\circ} 41^{\prime} 51.8^{\prime \prime}$, E $19^{\circ}$ 40' 26.9" and N 42 41'33.9”, E 19'40'04.9”, 1,850-2,050 m, 29.07.2008, leg. Papp, B. and Erzberger, P.

\section{Methods}

Material was collected during several field trips in 1998, 2006 and 2008. The investigated area is shown in Figure 1. Stream valleys, springs, forests and alpine grasslands were investigated, and bryophytes were collected from different substrates (soil, exposed and shaded rocks, tree bark, and decaying wood). Floristical results are considered as new to Montenegro, if there are no corresponding records in the bryophyte checklist of Montenegro (DRAGIĆEVIĆ and VELJIĆ 2006), the liverwort checklists of SE Europe and the Mediterranean (Ros et al. 2007, SABovljević and NATCHEVA 2006), the moss checklist of SE Europe (Ros et al. 2013, SABOVLJEviĆ et al. 2008) or other works containing additional data for Montenegro (Erzberger and PApp 2007, Erzberger et al. 2008, PAPP and ERZBerger 2007, 2011, PAPP et al. 2008, 2013a).

The specimens have been shared between the participating parties and are deposited in the Herbarium of the Hungarian Natural History Museum, Budapest, in the Natural History Museum of Montenegro and in the Herbarium of the Botanical Museum Berlin-Dahlem.

The nomenclature for liverworts follows GROLLE and LONG (2000), for mosses Hill et al. (2006) with the exception of Conocephalum salebrosum, which follows SZWEYKOWSKi et al. (2005).

The distribution of new and interesting species in SE European countries is given according to the checklists of SE Europe (SABOVLJEVIĆ and NATCHEVA 2006, SABovljević et al. 2008) and the Mediterranean (Ros et al. 2007, 2013) or otherwise cited.

For the evaluation of nature conservation merit of the species recorded, the following literature sources were used: the Red data book of European bryophytes (ECCB 1995), and the bryophyte red list of Serbia and Montenegro (SABOVlJEvić et al. 2004). Their symbols are as follows for the Red data book 
of European bryophytes (ECCB 1995): $\mathrm{Ex}=$ extinct, $\mathrm{Ev}=$ vanished, $\mathrm{E}=$ endangered, $\mathrm{V}=$ vulnerable, $\mathrm{R}=$ rare, $\mathrm{K}=$ insufficiently known, $\mathrm{T}=$ taxonomically illdefined taxa, $\mathrm{RT}=$ regionally threatened species and $\mathrm{NT}=$ not threatened. In the bryophyte red list of Serbia and Montenegro (SABOVLJEVIĆ et al. 2004): EX = extinct, $\mathrm{CR}=$ critically endangered, $\mathrm{EN}=$ endangered, $\mathrm{VU}=$ vulnerable, $\mathrm{LR}=$ lower risk or near threatened and DD = data deficient.

\section{RESULTS AND DISCUSSION}

200 bryophytes ( 43 liverworts and 157 mosses) were collected in the Komovi Mts. Four mosses proved to be new to Montenegro (marked with *). The numerals following the species names refer to the collection sites described above.

\section{Hepaticae}

Apometzgeria pubescens (Schrank) Kuwah. - 10: limestone rock Athalamia hyalina (Sommerf.) S. Hatt. - 11: soil among limestone rock

Barbilophozia hatcheri (A. Evans) Loeske - 7: limestone rock; 10: limestone rock and decaying wood Barbilophozia lycopodioides (Wallr.) Loeske - 2: soil; bottom of limestone rock; 6: soil in mixed forest; 10: bark of Fagus sylvatica; 11: siliceous rock

Blepharostoma trichophyllum (L.) Dumort. - 2, 10: decaying wood; 11: limestone rock

Cephalozia bicuspidata (L.) Dumort. - 3: at a spring; 7: soil

Cephalozia connivens (Dicks.) Lindb. - 10: decaying wood

Cephaloziella divaricata (Sm.) Schiffn. - 11: soil among limestone rock

Chiloscyphus pallescens (Ehrh. ex Hoffm.) Dumort. - 7: soil and limestone rock

Conocephalum salebrosum Szweyk., Buczkowska et Odrzykoski - 8: soil in deciduous forest

Jungermannia atrovirens Dumort. - 10: soil (conf./det. J. Váňa); 11: limestone rock (conf. S. Ştefănuț, det. J. Váňa)

Jungermannia confertissima Nees - 11: soil among limestone rocks

Jungermannia gracillima Sm. - 3, 10: soil; 11: soil among limestone rocks

Jungermannia byalina Lyell - 5: soil; 8: soil in mixed forest; 6: soil in deciduous forest

Leiocolea bantriensis (Hook.) Jörg. - 5, 11 (det. J. Váňa): soil

Leiocolea collaris (Nees) Schljakov - 8: limestone in mixed forest; 10: limestone rock; 11: soil among limestone rocks

Leiocolea beterocolpos (Thed. ex Hartm.) H. Buch - 11: limestone rock

Lepidozia reptans (L.) Dumort. - 10: decaying wood

Lophocolea beterophylla (Schrad.) Dumort. - 1: decaying wood in deciduous forest; 8: decaying wood in mixed forest

Lophozia ascendens (Warnst.) R. M. Schust. - 10: decaying wood

Lophozia longiflora (Nees) Schiffn. - 10: decaying wood (conf. S. Ştefănuț)

Lophozia sudetica (Nees ex Huebener) Grolle - 2: soil among limestone rocks; 3: soil covering siliceous rock; 7: siliceous rock

Marchantia polymorpha L. subsp. polymorpha - 5: soil; 8: soil in mixed forest; 9: soil in mixed forest and decaying wood

Marchantia polymorpha L. subsp. ruderalis Bischl. et Boisselier - 6: mixed forest, wet soil with Brachythecium rivulare 
Marsupella funckii (F. Weber et D. Mohr) Dumort. - 7: at a spring

Metzgeria furcata (L.) Dumort. - 1: limestone rock in deciduous forest and bark of Fagus sylvatica; 3, 7: bark of Fagus sylvatica; 10: limestone rock and bark of Fagus sylvatica and Picea abies

Nardia scalaris Gray - 3: wet rock and soil; 7: soil

Pedinophyllum interruptum (Nees) Kaal. - 10: limestone rock

Pellia endiviifolia (Dicks.) Dumort. - 7: soil and limestone rock; 9: soil in mixed forest and decaying wood

Pellia neesiana (Gottsche) Limpr. - 7: at a spring

Plagiochila porelloides (Torrey ex Nees) Lindenb. - 1: decaying wood and limestone rock; 8: on decaying wood and soil; 10: soil, limestone rock and bark of Picea abies; 11: limestone rock

Porella cordaeana (Huebener) Moore - 1, 6: limestone rock in deciduous forest; 3, 7: bark of Fagus sylvatica; 8, 10, 11: limestone rock; 9: decaying wood

Preissia quadrata (Scop.) Nees - 8: limestone in mixed forest; 10, 11: limestone rock

Radula complanata (L.) Dumort. - 1: decaying wood, limestone rock and bark of Fagus sylvatica; 6: limestone rock and bark of Fagus sylvatica; 8: scree and limestone rock; 10: limestone rock and bark of Picea abies

Reboulia hemisphaerica (L.) Raddi - 10, 11: soil among limestone rocks

Riccia sorocarpa Bisch. - 11: soil among limestone rocks

Scapania aequiloba (Schwägr.) Dumort. - 1, 8: limestone rock in deciduous forest; 2, 11: limestone rock; 6: limestone rock in mixed forest and meadow; 10: limestone rock and decaying wood

Scapania aspera M. Bernet et Bernet - 10: limestone rock

Scapania calcicola (Arnell et J. Perss.) Ingham - 2: soil among limestone rocks and decaying wood

Scapania cuspiduligera (Nees) Müll. Frib. - 10: limestone rocky grassland

Scapania mucronata H. Buch - 11: soil among limestone rocks (conf. S. Ştefănuț)

Scapania umbrosa (Schrad.) Dumort. - 10: decaying wood

Scapania undulata (L.) Dumort. - 3, 7: rock at a spring

\section{Musci}

Abietinella abietina (Hedw.) M. Fleisch. - 2: soil

Amblystegium confervoides (Brid.) Schimp. - 10: limestone rock

Amblystegium subtile (Hedw.) Schimp. - 10: bark of Fagus sylvatica

Anoectangium aestivum (Hedw.) Mitt. - 11: limestone rock

Anomodon rugelii (Müll. Hal.) Keissl. - 1: limestone rock in deciduous forest

Antitrichia curtipendula (Hedw.) Brid. - 9: bark of Fagus sylvatica

Atrichum undulatum (Hedw.) P. Beauv. - 8: soil

Barbula unguiculata Hedw. - 10: limestone rock

Bartramia ithyphylla Brid. - 10: soil; 11: soil among limestone rock

Brachytheciastrum velutinum (Hedw.) Ignatov et Huttunen - 1: soil in deciduous forest and decaying wood; 2: decaying wood; 6, 8: soil in mixed forest, decaying wood and limestone rock; 7: bark of Fagus sylvatica; 10: soil, limestone rock and bark of Fagus sylvatica; 11: limestone rock Brachythecium geheebi Milde - 10: limestone rock

Brachythecium glareosum (Bruch ex Spruce) Schimp. - 1: limestone rock in deciduous forest; 8: soil in deciduous forest; 10: soil and limestone rock; 11: soil among limestone rock

Brachythecium rivulare Schimp. - 5: limestone rock; 6, 9: wet soil in mixed forest; 7: at a spring Brachythecium rutabulum (Hedw.) Schimp. - 5: limestone rock

Brachythecium salebrosum (Hoffm. ex F. Weber et D. Mohr) Schimp. - 10: limestone rock

Brachythecium tommasinii (Sendtn. ex Boulay) Ignatov et Huttunen - 8: soil; 10: limestone rock 
Bryoerythrophyllum recurvirostrum (Hedw.) P. C. Chen - 1: limestone rock in deciduous forest; 2: limestone rock; 6: soil mixed forest; 8: decaying wood in mixed forest; 11: soil among limestone rock

Bryum argenteum Hedw. - 2: soil

Bryum caespiticium Hedw. - 8: soil in deciduous forest (det. W. Schröder)

Bryum capillare Hedw. - 1: limestone rock in deciduous forest; 8: soil in deciduous forest; 11: limestone rock

Bryum creberrimum Taylor - 2: soil and limestone rocks (det. W. Schröder)

Bryum elegans Nees - 1: limestone rock in deciduous forest; 2 : decaying wood and limestone rock; 6: soil, limestone rock in mixed forest and decaying wood; 10: limestone rock; 11: soil among limestone rock

Bryum moravicum Podp. - 1: limestone rock and decaying wood in deciduous forest; 8: limestone rock in mixed forest; 9: decaying wood and limestone rock in deciduous forest 10: bark of Fagus sylvatica

Bryum pallens Sw. ex anon. - 5: at the spring (det. W. Schröder); 2, 8: limestone rock in mixed forest; 10: limestone rocky grassland (conf./det. W. Schröder)

Bryum pallescens Schleich. ex Schwägr. - 4: siliceous rock (det. W. Schröder); 8: soil in deciduous forest

Bryum pseudotriquetrum (Hedw.) P. Gaertn. et al. - 4, 5, 9: soil

Bryum schleicheri DC. - 5, 9: limestone rocks at a stream (conf./det. W. Schröder)

Bryum turbinatum (Hedw.) Turner - 9: limestone rocks at a stream

Buxbaumia viridis (Moug. ex Lam. et DC.) Brid. ex Moug. et Nestl. - 10: decaying wood

Campyliadelphus chrysophyllus (Brid.) R. S. Chopra - 11: limestone rock

Campylium protensum (Brid.) Kindb. - 8: decaying wood; 10: limestone rock

Campylium stellatum (Hedw.) Lange et C. E. O. Jensen - 4: soil; 5: soil and limestone rock; 11: limestone rock

Campylophyllum halleri (Hedw.) M. Fleisch. - 1: limestone rock in deciduous forest; 6: soil; 8: limestone rock, scree, decaying wood in mixed forest; 10, 11: limestone rock

${ }^{*}$ Campylopus pyriformis (Schultz) Brid. - 7: siliceous rock

Ceratodon purpureus (Hedw.) Brid. - 7: in meadow; 8, 10: soil; 9: soil in deciduous forest

Ctenidium molluscum (Hedw.) Mitt. - 1, 2, 8, 11: limestone rock; 6: limestone rock in mixed forest; 10: soil and limestone rock

Cynodontium polycarpon (Hedw.) Schimp. - 7: soil in deciduous forest

Dichodontium palustre (Dicks.) M. Stech - 7: at a spring

Dichodontium pellucidum (Hedw.) Schimp. - 7: wet siliceous rock and soil at spring; 9: soil mixed forest; 11: limestone rock

Dicranella varia (Hedw.) Schimp. - 2, 10: soil among limestone rocks

Dicranoweisia crispula (Hedw.) Milde - 7: siliceous rock

Dicranum scoparium Hedw. - 3, 7: soil; 10: limestone rock and bark of Picea abies; 11: soil among limestone rock

Dicranum tauricum Sapjegin - 9: decaying wood in mixed forest; 10: bark of Picea abies and decaying wood

Didymodon fallax (Hedw.) R. H. Zander - 6: soil in mixed forest; 10: limestone rock; 11: soil among limestone rock and limestone rock

*Didymodon nicholsonii Culm. - 11: limestone rock at a rivulet

Didymodon rigidulus Hedw. - 10, 11: limestone rock

Didymodon tophaceus (Brid.) Lisa - 10: soil

Distichium capillaceum (Hedw.) Bruch et Schimp. - 2, 10, 11: limestone rock; 6: soil in mixed forest 
Distichium inclinatum (Hedw.) Bruch et Schimp. - 2, 10: soil among limestone rocks; 11: limestone rock

Ditrichum flexicaule (Schwägr.) Hampe - 2, 11: limestone rock; 3: limestone rock in mixed forest Ditrichum gracile (Mitt.) Kuntze - 2: soil and limestone rocks; 6, 8: limestone rock in mixed forest; 10, 11: limestone rock

Ditrichum beteromallum (Hedw.) E. Britton - 10: soil among limestone rocks

Ditrichum pusillum (Hedw.) Hampe - 7: soil in deciduous forest

Drepanocladus polygamus (Schimp.) Hedenäs - 11: limestone rock

Encalypta ciliata Hedw. - 11: limestone rock

Encalypta streptocarpa Hedw. - 3: in a meadow; 6, 8: soil in mixed forest; 10, 11: limestone rock

Eurhynchiastrum pulchellum (Hedw.) Ignatov et Huttunen var. pulchellum - 3: decaying wood in mixed forest, on decaying wood, with Ditrichum flexicaule; 11: limestone rock

Eurhynchiastrum pulchellum (Hedw.) Ignatov et Huttunen var. diversifolium (Schimp.) Ochyra et Żarnowiec - 11: soil among limestone rock

Eurhynchiastrum pulchellum (Hedw.) Ignatov et Huttunen var. praecox (Hedw.) Ochyra et Żarnowiec - 10: limestone rock

Fissidens bryoides Hedw. - 6: soil in mixed forest

Fissidens dubius P. Beauv. - 10, 11: limestone rock

Fissidens taxifolius Hedw. - 8: soil in mixed forest; 10: soil and limestone rock; 11: soil among limestone rock

Fissidens viridulus (Sw. ex anon.) Wahlenb. - 11: soil among limestone rock

Funaria hygrometrica Hedw. - 7: in a meadow

Grimmia anomala Hampe ex Schimp. - 11: siliceous rock

Grimmia caespiticia (Brid.) Jur. - 4: dry siliceous rock

Grimmia mueblenbeckii Schimp. - 7, 8, 11: siliceous rock

Gymnostomum aeruginosum Sm. - 11: soil among limestone rock

Gymnostomum calcareum Nees et Hornsch. - 5: limestone rock at a spring

Herzogiella seligeri (Brid.) Z. Iwats. - 8: decaying wood in mixed forest; 10: decaying wood

Homalothecium lutescens (Hedw.) H. Rob. - 1, 11: limestone rock

Homalothecium philippeanum (Spruce) Schimp. - 8, 10, 11: limestone rock

Homalothecium sericeum (Hedw.) Schimp. - 2, 5, 8, 10, 11: limestone rock

Hylocomium splendens (Hedw.) Schimp. - 2: soil in deciduous forest; 3: soil; 11: limestone rock

*Hypnum procerrimum Molendo - 11: limestone rock

Isopterygiopsis pulchella (Hedw.) Z. Iwats. - 11: limestone rock

Isothecium alopecuroides (Lam. ex Dubois) Isov. - 9: bark of Fagus sylvatica; 11: limestone rock

Lescuraea saxicola (Schimp.) Molendo - 1: limestone rock in deciduous forest; 10: limestone rock

Leucodon sciuroides (Hedw.) Schwägr. - 8, 9, 10: bark of Fagus sylvatica

Meesia uliginosa Hedw. - 2: soil among limestone rocks

Mnium lycopodioides Schwägr. - 10: bottom of Picea abies

Mnium stellare Hedw. - 8: soil in mixed forest; 9: soil in deciduous forest; 10: limestone rock

Mnium thomsonii Schimp. - 2, 10, 11: limestone rock

Myurella julacea (Schwägr.) Schimp. - 2, 10, 11: soil among limestone rocks

Neckera menziesii Drumm. - 10: limestone rock

Orthothecium intricatum (Hartm.) Schimp. - 11: limestone rock

Orthothecium rufescens (Dicks. ex Brid.) Schimp. - 2, 11: limestone rock

Orthotrichum pallens Bruch ex Brid. - 10: bark of Fagus sylvatica

Orthotrichum stramineum Hornsch. ex Brid. - 10: bark of Fagus sylvatica

Orthotrichum striatum Hedw. - 8, 10: bark of Fagus sylvatica 
Oxyrrhynchium hians (Hedw.) Loeske - 6: limestone rock in mixed forest

Palustriella commutata (Hedw.) Ochyra var. commutata - 2: limestone rock at a spring; 5: limestone rocks at a stream

Palustriella commutata (Hedw.) Ochyra var. sulcata (Lindb.) Ochyra - 5: limestone rocks at a stream Palustriella decipiens (De Not.) Ochyra - 5, 7: limestone rock at a spring

Palustriella falcata (Brid.) Hedenäs - 5: limestone rock at a spring

Paraleucobryum sauteri (Bruch et Schimp.) Loeske - 10: decaying wood

Philonotis arnellii Husn. - 11: soil among limestone rocks

Philonotis fontana (Hedw.) Brid. - 4, 5: soil at a stream

Philonotis seriata Mitt. - 3, 4, 5: in a meadow; 7: siliceous rock and soil at a spring

Philonotis tomentella Molendo - 4: soil at a stream, 7: at a spring

Plagiobryum zieri (Hedw.) Lindb. - 11: limestone rock

Plagiomnium affine (Blandow ex Funck) T. J. Kop. - 7: soil at a spring

Plagiomnium rostratum (Schrad.) T. J. Kop. - 9: soil in deciduous forest; 10: limestone rock

Plagiopus oederianus (Sw.) H. A. Crum et L. E. Anderson - 2, 10, 11: limestone rock

Plagiothecium cavifolium (Brid.) Z. Iwats. - 11: soil over limestone rock

Plagiothecium denticulatum (Hedw.) Schimp. - 3, 7: bark of Fagus sylvatica; 10: bark of Picea abies

Platydictya jungermannioides (Brid.) H. A. Crum - 8: limestone rock in mixed forest; 10: limestone rock

Pogonatum aloides (Hedw.) P. Beauv. - 2: soil

Pogonatum urnigerum (Hedw.) P. Beauv. - 10: soil

Poblia cruda (Hedw.) Lindb. - 1: decaying wood in deciduous forest; 2: soil and decaying wood; 6: soil and the bottom of limestone rock; 8: soil in mixed forest; 10: limestone rock and bottom of Picea abies; 11: soil among limestone rocks

Pohlia drummondii (Müll. Hal.) A. L. Andrews - 11: soil among limestone rocks

Poblia nutans (Hedw.) Lindb. - 7, 10: soil

Pohlia wablenbergii (F. Weber et D. Mohr) A. L. Andrews - 4: soil at a stream

Polytrichastrum alpinum (Hedw.) G. L. Sm. - 7, 8, 9, 10: soil; 11: soil among limestone rocks

Polytrichastrum formosum (Hedw.) G. L. Sm. - 1, 8, 9: soil in deciduous and mixed forest; 10: soil and limestone rock; 11: soil among limestone rocks

Polytrichum juniperinum Hedw. - 2: decaying wood; 3: soil; 8: soil in mixed forest; 9: soil in deciduous forest; 10: soil and bark of Fagus sylvatica; 11: soil among limestone rocks

Polytrichum piliferum Hedw. - 7: soil

Pseudoleskea incurvata (Hedw.) Loeske - 1: limestone rock in deciduous forest; 3: limestone rock and bark of Fagus sylvatica; 6, 8, 10: limestone rock; 9: decaying wood in deciduous forest

Pseudoleskea saviana (De Not.) Latzel - 1, 9: limestone rock and bark of tree in deciduous forest; 7, 8: bark of Fagus sylvatica and decaying wood; 10: limestone rock and bark of Fagus sylvatica; 11: limestone rock

Pseudoleskeella catenulata (Brid. ex Schrad.) Kindb. - 11: limestone rock

Pseudoleskeella nervosa (Brid.) Nyholm - 1: bark of Fagus sylvatica; 8, 9: decaying wood in deciduous forest; 10: limestone rock and bark of Fagus sylvatica

Pterigynandrum filiforme Hedw. - 8, 9: decaying wood in deciduous forest; 10: bark of Fagus sylvatica and Picea abies

Ptychodium plicatum (Schleich. ex F. Weber et D. Mohr) Schimp. - 1, 2, 8: limestone rock in deciduous forest; 6 : limestone rock in mixed forest; 10, 11: limestone rock

Racomitrium canescens (Hedw.) Brid. - 3, 7: soil

Racomitrium elongatum Ehrh. ex Frisvoll - 3, 6, 7, 8, 9, 10 (conf/rev. H. Bednarek-Ochyra): soil; 11: siliceous rock 
Rhizomnium pseudopunctatum (Bruch et Schimp.) T. J. Kop. - 5: soil at a spring

Rhizomnium punctatum (Hedw.) T. J. Kop. - 8: decaying wood in mixed forest; 9: soil and decaying wood in mixed forest; 10: decaying wood

*Rhynchostegiella tenuicaulis (Spruce) Kartt. - 1: bark of Fagus sylvatica; 2: limestone rock

Rhynchostegium murale (Hedw.) Schimp. - 10: limestone rock

Rhytidiadelphus triquetrus (Hedw.) Warnst. - 2, 3, 6, 10: soil; 11: soil among limestone rocks

Rhytidium rugosum (Hedw.) Kindb. - 2: soil

Saelania glaucescens (Hedw.) Broth. - 2, 10, 11: soil among limestone rocks

Sanionia uncinata (Hedw.) Loeske - 8: decaying wood in mixed forest; 10: limestone rock and decaying wood

Schistidium apocarpum (Hedw.) Bruch et Schimp. - 11: limestone rock

Schistidium atrofuscum (Schimp.) Limpr. - 11: limestone rock

Schistidium brunnescens Limpr. subsp. griseum (Nees et Hornsch.) H. H. Blom - 2, 11: limestone rock

Schistidium confertum (Funck) Bruch et Schimp. - 11: siliceous rock

Schistidium crassipilum H. H. Blom - 1: limestone rock in deciduous forest; 2, 3, 6, 8: limestone rock in mixed forest; 10: limestone rock (det. W. Schröder)

Schistidium dupretii (Thér.) W. A. Weber - 8, 10: limestone rock

Schistidium pruinosum (Wilson ex Schimp.) G. Roth - 11: siliceous rock

Schistidium robustum (Nees et Hornsch.) H. H. Blom - 11: limestone rock

Sciuro-bypnum populeum (Hedw.) Ignatov et Huttunen - 10: bark of Fagus sylvatica

Syntrichia norvegica F. Weber - 1: limestone rock in deciduous forest; 10, 11: limestone rock

Syntrichia ruralis (Hedw.) F. Weber et D. Mohr - 9: decaying wood in deciduous forest; 10: limestone rock and bark of Fagus sylvatica

Syntrichia virescens (De Not.) Ochyra - 10: bark of Fagus sylvatica

Thuidium assimile (Mitt.) A. Jaeger - 2: soil

Timmia austriaca Hedw. - 8: soil in mixed forest; 10: limestone rock; 11: soil among limestone rocks Timmia bavarica Hessl. - 6: soil and limestone rock; 11: limestone rock

Tortella bambergeri (Schimp.) Broth. - 10: limestone rock

Tortella inclinata (R. Hedw.) Limpr. - 10: limestone rocky grassland

Tortella tortuosa (Hedw.) Limpr. var. tortuosa - 1: limestone rock in deciduous forest; 3, 9: limestone rock; 2, 6, 8: limestone rock in mixed forest; 10: bark of Fagus sylvatica; 10, 11: limestone rock

Tortella tortuosa (Hedw.) Limpr. var. fragilifolia (Jur.) Limpr. - 2: limestone rock

Tortula hoppeana (Schultz) Ochyra - 2, 10: soil among limestone rocks

Tortula subulata Hedw. - 6: soil; 11: soil among limestone rocks

Trichostomum crispulum Bruch - 2, 6: soil; 11: limestone rock

Weissia controversa Hedw. var. controversa - 11: limestone rock

Weissia controversa Hedw. var. crispata (Nees et Hornsch.) Nyholm - 10: soil

Four moss species are reported for the first time in Montenegro.

Campylopus pyriformis is a sub-Atlantic species (DÜLL 1984). In SE Europe

it is known only from Croatia, Romania and Slovenia (SABovljević et al. 2008). Recently it has been also reported from the Former Yugoslav Republic of Macedonia (PAPp and ERzberger 2012). According to the red lists it is regionally extinct (RE) in Slovenia (MARTINČIČ 1992) and near threatened (NT) in Romania (ŞTEFĂNUȚ and GoIA 2012). 
Didymodon nicholsonii is a sub-Atlantic, sub-Mediterranean species (DÜLL 1984). In SE Europe it is known only from Greece (SABOVLJEVIĆ et al. 2008).

Hypnum procerrimum is a northern sub-Atlantic, alpine element (DÜLL 1985). In SE Europe it is known only from Bosnia-Herzegovina, Bulgaria, Croatia, Romania, Serbia and Slovenia (SABOVLJEvić et al. 2008). According to the red lists it is critically endangered (CR) in Bulgaria (NATCHEVA et al. 2006) and datadeficient (DD) in Slovenia (MARTINČIČ 1992).

Rhynchostegiella tenuicaulis is a montane species of temperate zone of Europe (DüLL 1985). In SE Europe it is known only from Bulgaria, Greece and Romania (SABOvLJEvić et al. 2008). Recently it has been also reported from Croatia (PAPP et al. 2013b). According to the red lists it is data-deficient (DD) in Bulgaria (NATCHEVA et al. 2006) and vulnerable (VU) in Romania (ŞTEFĂNUȚ and GoiA 2012).

Eight species (Jungermannia hyalina, Nardia scalaris, Scapania mucronata, Dichodontium palustre, Grimmia anomala, Schistidium dupretii, S. pruinosum, Syntrichia virescens) have been reported recently from the Bjelasica Mts (PAPP et al. 2013a) and their records from the Komovi Mts represent the second locality in the country.

Pellia neesiana had only a very old doubtful record from Montenegro according to DRAGićEvić and VelJIĆ (2006), then it has recently been reported from the Bjelasica Mts (PAPP et al. 2013a). Its record from the Komovi Mts represents the third locality in the country.

Scapania cuspiduligera has been recently reported from the Durmitor Mts (PAPP and ERzberger 2010) and its record from the Komovi Mts represents the second locality in the country.

Anoectangium aestivum has been recently reported from the Tara canyon (PAPP and Erzberger 2011) and its record from the Komovi Mts represents the second locality in the country.

Rhizomnium punctatum was reported for the first time in Montenegro by MartinčIČ (2006) from the Prokletije Mts and its record from the Komovi Mts represents the second locality in the country.

Nature conservation merit of the bryophyte flora

Six species are included in the Red data book of European bryophytes (ECCB 1995).

Lophozia ascendens - It is known from the Bjelasica Mts (ERzberger et al. 2008, PAPP et al. 2013a) and from the Durmitor Mts (PAPP and ERZBERger 2010). Threat status: $\mathrm{R}$ in the Red data book of European bryophytes. 
Brachythecium geheebi - There are recent records from the Durmitor Mts (Dragićević and Veljić 2006) and the Bjelasica Mts (PApp et al. 2013a). Threat status: $\mathrm{R}$ in the Red data book of European bryophytes, LR in Montenegro.

Buxbaumia viridis - Recently, several extant populations have been discovered in Montenegro (DRAGIĆEvić et al. 2011). Threat status: listed in the Bern Convention and the European Union Habitats and Species Directive (ECCB 1995), VU in the Red data book of European bryophytes, CR in Montenegro.

Grimmia caespiticia - It was collected in several localities in the Bjelasica Mts (PAPp et al. 2013a) and also known from the Prokletije Mts (MARTinčič 2006). Threat status: $\mathrm{R}$ in the Red data book of European bryophytes, VU in Montenegro.

Paraleucobryum sauteri - It has a recent record from the Bjelasica Mts (PAPP et al. 2013a). Threat status: $\mathrm{R}$ in the Red data book of European bryophytes, VU in Montenegro.

Pseudoleskea saviana - Not rare in Montenegro evidenced by several records (MARTinčič 2006, PAPP and ERZBerger 2010, 2011). Threat status: RT in the Red data book of European bryophytes, VU in Montenegro.

The following 12 species are also included in the red list of Montenegro (SABOVlJEVić et al. 2004).

Athalamia hyalina - From Montenegro there are two old records from the Orjen Mts collected at the beginning of the last century (DRAGIĆEvić and VeLjić 2006). Recently recorded in the Durmitor Mts (PAPP and ERzBerger 2010) and the Bjelasica Mts (PAPP et al. 2013a). Threat status: CR in Montenegro.

Jungermannia gracillima - Known from the Durmitor Mts (ERZBERger and Papp 2007, Papp and Erzberger 2010) and the Bjelasica Mts (Papp et al. 2013a). Threat status: EN in Montenegro.

Leiocolea collaris - In spite of the red list status in Montenegro it is apparently not rare in the country as evidenced by several records (PAPP and ERZBERGER 2007, 2010, PAPP et al. 2008, 2013a). Threat status: VU in Montenegro.

Leiocolea heterocolpos - In Durmitor and in Bjelasica Mts it is found in several localities (PAPP and ERzBerger 2010, PAPP et al. 2013a). Threat status: VU in Montenegro.

Amblystegium confervoides - From Montenegro it has an old and a recent record (DragićEvić and Veljić 2006). Threat status: DD in Montenegro.

Anomodon rugelii - From Montenegro there are two old and one recent records (DRAGIĆEVIĆ and VeljIĆ 2006). Threat status: EN in Montenegro.

Bryum creberrimum - From Montenegro it has one recent and four old records (DRAGićEVIĆ and VeLjić 2006). Threat status: DD in Montenegro. 
Encalypta ciliata - In Montenegro it has two recent records from the Durmitor Mts (PApp and Erzberger 2010) and the Bjelasica Mts (PApp et al. 2013a). Threat status: VU in Montenegro.

Meesia uliginosa - In Montenegro it has two old records from the Durmitor Mts (DRAGIĆEviĆ and VeLjIĆ 2006). Threat status: VU in Montenegro.

Philonotis arnellii - In Montenegro it has one recent and three old records from the surroundings of Herceg Novi (Dragićević and Veljić 2006, Papp and ERzBerger 2007) and two recent records from the Lovćen Mts (PAPP and Erzberger 2007) and the Durmitor Mts (PApP and Erzberger 2010). Threat status: DD in Montenegro.

Racomitrium elongatum - Seems to be not rare in Montenegro with several recent records from the Durmitor, Prokletije and Bjelasica Mts (DragićEvić and Veljić 2006, Martinčič 2006, Papp and Erzberger 2010, Papp et al. 2013a). Threat status: DD in Montenegro.

Timmia bavarica - It has several records from the Prokletije Mts (MARTINČIČ 2006) and two records from the Durmitor Mts (PAPP and Erzberger 2010). Threat status: VU in Montenegro.

\section{CONCLUSIONS}

The geological diversity and other favourable environmental factors of the Komovi Mts help maintain a rich bryophyte flora. The mountains of Montenegro are mostly composed of limestone, acidic bedrock is rather rare. Therefore, parts of the Komovi Mts with acidic bedrocks are of special importance for the bryophyte diversity of the country. This is documented by the occurrences of rare liverworts, such as Lophozia sudetica, Marsupella funckii, Nardia scalaris, Pellia neesiana, and rare mosses, like Grimmia anomala, G. caespiticia, and Schistidium pruinosum. Due to the high elevation and mountain climate, the bryophyte flora of the forests and alpine grasslands contain numerous boreal, subalpine and alpine elements, among them several rarities, including Athalamia byalina, Jungermannia confertissima, Leiocolea bantriensis, L. heterocolpos, Scapania cuspiduligera, S. mucronata, Anoectangium aestivum, Brachythecium geheebi, Bryum schleicheri, Dichodontium palustre, Distichium inclinatum, Drepanocladus polygamus, Encalypta ciliata, Hypnum procerrimum, Isopterygiopsis pulchella, Lescuraea saxicola, Meesia uliginosa, Orthothecium rufescens, Palustriella decipiens, Philonotis tomentella, Platydictya jungermannioides, Poblia drummondii, Rhizomnium pseudopunctatum, Syntrichia norvegica, and Timmia bavarica. Most of these are calciphilous species. Decaying wood in old growth forests also support populations of many rarities like Cephalozia connivens, Lophozia ascendens, L. longiflora, Scapania umbrosa, Buxbaumia viridis and Paraleucobryum sauteri. 
Ackowledgements - We gratefully acknowledge an EU Synthesys2 grant, which funded the research visit of the second author to the Hungarian Natural History Museum (project No. HUTAF-2276): Taxonomic and ecological analyses of moss specimens collected in Montenegro (Bjelasica and Komovi Mts); studies on the distribution of nationally rare, red-listed and European endangered species in Montenegro. We are indebted to Wiebke Schröder (Ludwigsstadt-Ebersdorf), Halina Bednarek-Ochyra (Kraków), Sorin Ştefănuț (Bucureşti) and Jiří Váňa (Praha) for their help in confirmation, identification or revision of certain problematic specimens.

\section{REFERENCES}

Dragićević, S. and Veljić, M. (2006): Pregled mahovina Crne Gore. - Prirodnjački Muzej Crne Gore, Podgorica, 99 pp.

Dragićević, S., PAPp, B. and Erzberger, P. (2011): Distribution of Buxbaumia viridis (Moug. ex Lam. \& DC.) Brid. ex Moug. \& Nestl. (Bryophyta) in Montenegro. - Acta Bot. Croat. 71(2): 1-6. http://dx.doi.org/10.2478/v10184-011-0066-1

DülL, R. (1984): Distribution of the European and Macaronesian mosses (Bryophytina) I. - Bryol. Beiträge 4: 1-109.

DüLL, R. (1985): Distribution of the European and Macaronesian mosses (Bryophytina) II. Bryol. Beiträge 5: 110-232.

ECCB (1995): Red data book of European bryophytes. - European Committee for Conservation of Bryophytes, Trondheim, $291 \mathrm{pp}$.

Erzberger, P. and PAPp, B. (2007): New and noteworthy bryophyte records from Montenegro and Serbia. - Willdenowia 37: 339-351. http://dx.doi.org/10.3372/wi.37.37124

Erzberger, P., PAPP, B. and Dragićević, S. (2008): Notes on some newly recorded bryophytes from Montenegro. - J. Bryol. 30: 167-170. http://dx.doi.org/10.1179/174328208X300570

Grolle, R. and Long, D. G. (2000): An annotated check-list of the Hepaticae and Anthocerotae of Europe and Macaronesia. - J. Bryol. 22: 103-140. http://dx.doi.org/10.1179/jbr.2000. 22.2.103

Hill, M. O., Bell, N., Bruggeman-Nannenga, M. A., Brugués, M., Cano, M. J., Enroth, J., Flatberg, K. I., Frahm, J.-P., Gallego, M. T., Garilleti, R., Guerra, J., Hedenäs, L., Holyoak, D. T., Hyvönen, J., Ignatov, M. S., Lara, F., Mazimpaka, V., Muñoz, J. and SÖDERSTRÖM, L. (2006): An annotated checklist of the mosses of Europe and Macaronesia. -J. Bryol. 28(3): 198-267. http://dx.doi.org/10.1179/174328206X119998

Kićović, D. M. and Dragović, R. M. (2000): Prirodne odlike i zaštita Komova. - Zaštita prirode, Beograde 52(1): 105-115.

LAKUŠıć, R. (1974): Specifičnosti flore i vegetacije Komova i Prokletija. - Tokovi, Ivangrad 9: 47-53.

MARTINČIČ, A. (1992): Rdeci seznam ogroženih listnatih mahov (Musci) v Sloveniji. - Varstvo Narave 18: 1-190.

MARTInČıČ, A. (2006): Moss flora of the Prokletije mountains (Serbia and Montenegro). - Hacquetia 5(1): 113-130.

Natcheva, R., Ganeva, A. and Spiridonos, G. (2006): Red list of the bryophytes in Bulgaria. Phytol. Balcan. 12(1): 55-62.

PAPp, B. and Erzberger, P. (2007): Contribution to the bryophyte flora of Montenegro. - Studia bot. hung. 38: 79-94. 
PApp, B. and Erzberger, P. (2010): Contribution to the bryophyte flora of Durmitor National Park, Montenegro. - Beih. Nova Hedwigia 138: 145-161.

PAPp, B. and Erzberger, P. (2011): Additions to the bryophyte flora of the Tara river canyon and Durmitor area, Montenegro. - Studia bot. hung. 42: 31-39.

PAPP, B. and ERzBerger, P. (2012): Contribution to the bryophyte flora of the Former Yugoslav Republic of Macedonia (FYROM). - Polish Bot. J. 57(1): 205-221.

Papp, B., Erzberger, P. and Dragićević, S. (2008): Contribution to the bryophyte flora of the Orjen Mts, Montenegro. - Studia bot. hung. 39: 101-112.

PAPp, B., Erzberger, P. and DragićEvić, S. (2013a): Contribution to the bryophyte flora of Bjelasica Mts (Montenegro). - Polish Bot. J. 58(1): 293-318. http://dx.doi.org/10.2478/pbj-2013-0030

Papp, B., Alegro, A., ŠEgota, V., ŠApić, I. and Vukelić, J. (2013b): Additions to the bryophyte flora of Croatia. - J. Bryol. 35(2): 140-143. http://dx.doi.org/10.1179/1743282013Y.0000000046

Petrović, D., Hadži ablahović, S., Vuksanović, S., Mačić, V. and Lakušić, D. (2012): Catalogue of habitat types of EU importance of Montenegro. - Podgorica and Beograde (mscr.).

Ros, R. M., Mazimpaka, V., Abou-Salama, U., Aleffi, M., Blockeel, T. L., Brugués, M., Cano, M. J., Cros, R. M., Dia, M. G., Dirkse, G. M., El-SaAdawi, W., Erda Ğ, A., Ganeva, A., González-Mancebo, J. M., Herrnstadt, I., Khalil, K., Kürschner, H., Lanfranco, E., Losada-Lima, A., Refai, M. S., Rodríguez-Nuñez, S., Sabovljević, M., Sérgio, C., Shabbara, H., Sim-Sim, M. and Söderström, L. (2007): Hepatics and Anthocerotes of the Mediterranean, an annotated checklist. - Cryptogamie, Bryol. 28(4): 351-437.

Ros, R. M., Mazimpaka, V., Abou-Salama, U., Aleffi, M., Blockeel, T. L., Brugués, M., Cros,

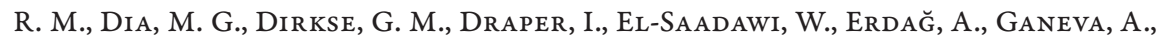
Gabriel, R., González-Mancebo, J. M., Granger, C., Herrnstadt, I., Hugonnot, V., Khalil, K., Kürschner, H., Losada-Lima, A., Luís, L., Mifsud, S., Privitera, M., Puglisi, M., Sabovljević, M., Sérgio, C., Shabbara, H. M., Sim-Sim, M., Sotiaux, A., Tacchi, R., Vanderpoorten, A. and Werner, O. (2013): Mosses of the Mediterranean, an annotated checklist. - Cryptogamie, Bryol. 34(2): 99-283. http://dx.doi.org/doi/10.782/cryb.v34.iss2.2013.99

SABovljević, M. and NatcheVA, R. (2006): A check-list of the liverworts and hornworts of Southeast Europe. - Phytol. Balcan. 12: 169-180.

Sabovljević, M., Cvetić, T. and Stevanović, V. (2004): Bryophyte red list of Serbia and Montenegro. - Biodiversity and Conservation 13: 1781-1790. http://dx.doi.org/10.1023/B:BIOC.0000029338.97776.66

Sabovljević, M., Natcheva, R., Tsakiri, E., Dihoru, G., Dragićević, S., ErdaĞ, A. and PAPP, B. (2008): Check-list of the mosses of SE Europe. - Phytol. Balcan. 14: 207-244.

ŞTEFĂnUT, S. and Goia, I. (2012): Checklist and red list of the bryophytes of Romania. - Nova Hedwigia 95(1-2): 59-104. http://dx.doi.org/10.1127/0029-5035/2012/0044

SZWEYKowsKi, J., BUCZKowsKa, K. and OdRZYKoski, I. J. (2005): Conocephalum salebrosum (Marchantiopsida, Conocephalaceae) - a new Holarctic liverwort species. - Pl. Syst. Evol. 253: 133-158. http://dx.doi.org/10.1007/s00606-005-0301-0 